\title{
Effect of Starvation on the Viability and Cellular Constituents of Zymomonas anaerobia and Zymomonas mobilis
}

\author{
By E. A. DAWES AND P. J. LARGE \\ Department of Biochemistry, The University, \\ Hull, HU6 7 RX \\ (Accepted for publication 29 September 1969)
}

\begin{abstract}
SUMMARY
Zymomonas anaerobia and Z. mobilis, grown on glucose + peptone + yeastextract medium, degraded no endocellular carbohydrate, DNA and protein even in prolonged starvation. No significant qualitative changes in protein content during starvation were detected by disc gel electrophoresis of crude extracts. Both organisms had a high content of RNA $(22 \% \mathrm{w} / \mathrm{w})$ which was degraded on starvation. In $Z$. anaerobia RNA decreased linearly to $5 \%$ of the dry weight in I $25 \mathrm{hr}$. With $Z$. mobilis, half the RNA was degraded in the first $24 \mathrm{hr}$ of starvation after which time the decline was much slower. $\mathrm{MgCl}_{2}$ (33 mM) prevented RNA breakdown. During growth, the intracellular ATP concentration increased from 0.5 to $\mathrm{I} \cdot 0 \mu \mathrm{g} . / \mathrm{mg}$. dry wt, but began to decrease exponentially in the last generation before growth ceased because of glucose exhaustion. Intracellular ATP content correlated with viability determined by slide culture. The addition of $33 \mathrm{~mm}-\mathrm{MgCl}_{2}$ to the starvation medium did not affect ATP content, but increased viability. On prolonged starvation (up to 7 days), populations whose viability had fallen to $3 \%$ possessed unimpaired ability to produce ATP from glucose; only after even longer starvation periods was this ability impaired.
\end{abstract}

\section{INTRODUCTION}

During recent years considerable attention has been focused on the nature of the endogenous metabolism of micro-organisms (for reviews, see Dawes \& Ribbons, I962, I964) although this work has been confined mainly to aerobic and facultatively anaerobic organisms. By investigating the changes in chemical composition which occur during starvation an insight can be afforded into the substrates utilized in endogenous metabolism and their relation to the viability of the organisms. Anaerobic bacteria, which obtain their energy by substrate-level phosphorylation reactions which are well charted, ought to be particularly amenable to investigation, especially in relation to the problem of 'maintenance energy' (Dawes \& Ribbons, I964). Forrest \& Walker (1965) studied the endogenous metabolism of the homofermentative organism Streptococcus faecalis which degrades glucose to lactate via the EmbdenMeyerhof pathway, and Thomas (1968) has investigated Streptococcus lactis. Accordingly, for the present work, Zymomonas anaerobia (McGill, Dawes \& Ribbons, I965; McGill, I966) and Z. mobilis (Stern, Wang \& Gilmour, I960; Dawes, Ribbons \& Large, I966) were chosen; they ferment glucose to ethanol and carbon dioxide by the Entner-Doudoroff (I952) pathway. Characteristic of this pathway is an energy yield of I mole ATP/mole glucose fermented, i.e. half that obtained by the EmbdenMeyerhof pathway (Elsden \& Peel, 1958). 
Most of our work was done with $Z$. anaerobia, but where the results with $Z$. mobilis differed, they have been reported. A preliminary account of the earlier part of this work has appeared (Large \& Dawes, 1966).

\section{METHODS}

Maintenance and growth of organisms. Zymomonas anaerobia (NCIB 8227) was maintained as a stabculture in agar and also in liquid medium. The basal liquid medium contained (g./1.): D-glucose, 20; Difco Bactopeptone, 10; Difco yeast extract, 10. When required, it was solidified with $15 \mathrm{~g}$. New Zealand agar substitute/1. (in the case of the slide cultures Io g. Oxoid Agar No. I/l. was used). Cultures were incubated at $30^{\circ}$. Zymomonas mobilis (NCIB 8938) was maintained in a similar manner. This organism grew with a doubling time of about $2 \mathrm{hr}$, compared with $3.5 \mathrm{hr}$ for Z. anaerobia.

Growth of larger quantities of either organism was achieved by transfer of an inoculum from the stock culture to $20 \mathrm{ml}$. sterile liquid medium. When this culture was gassing vigorously (after about $\mathrm{I} 2 \mathrm{hr}$ ) it was used to inoculate one or more litres of medium in round flat-bottomed flasks or aspirators filled to the neck. Zymomonas anaerobia attained stationary phase in $20 \mathrm{hr}$ at $30^{\circ}$, while $Z$. mobilis took 12 to $\mathrm{I} 5 \mathrm{hr}$.

For starvation experiments organisms were harvested aseptically in closed, sterile centrifuge bottles and the cultures were examined for contamination by phasecontrast microscopic examination of a wet smear.

Measurement of bacterial concentration. This was performed turbidimetrically with a Unicam SP 600 spectrophotometer at $570 \mathrm{~nm}$. Extinctions were related to population density by a dry wt calibration curve.

Preparation of washed suspensions for starvation experiments. After the appropriate period of growth organisms were harvested aseptically and washed in sterile phosphate buffer (below), $\mathrm{pH} 6.8$, and suspended in a suitable volume of the same buffer in a sterile measuring cylinder. In earlier experiments the suspension was then distributed into sterile $50 \mathrm{ml}$. conical flasks, which were flushed with $\mathrm{N}_{2}$, sealed with sterile silicone rubber stoppers and shaken at $30^{\circ}$. In later experiments the apparatus described by Dawes \& Holms (1958) was used in which nitrogen was bubbled through the suspension at $30^{\circ}$ via a sintered glass aerator. This apparatus bore a tap at the base through which samples could be removed aseptically, and had a small side arm into which substrate could be introduced aseptically at the start of the experiment, and subsequently tipped into the suspension without admitting air to the flask.

Preparation of extracts and disc electrophoresis. Zymomonas anaerobia organisms (about $70 \mathrm{mg}$. dry wt) were suspended in $2.5 \mathrm{ml}$. ice-cold $67 \mathrm{~mm}$-phosphate buffer (pH 6.8), disrupted for $1.5 \mathrm{~min}$. in an M.S.E. $60 \mathrm{~W}$ ultrasonic disintegrator and centrifuged for Io min. at $25,000 \mathrm{~g}$ to remove whole cells and debris. Samples of the supernatant fluid containing I00 $\mu \mathrm{g}$. protein were used for polyacrylamide disc electrophoresis as described by Davis (1964).

Determination of ATP. The ATP content of organisms was measured by the firefly luciferase technique based on the method of Forrest \& Walker (I965). Cole, Wimpenny \& Hughes (1967) pointed out that for accurate assay of intracellular ATP there should be as little lag as possible between harvesting of the organisms and extraction of the ATP; that, ideally, samples ought not to be harvested by centrifugation, and the samples should not be chilled. In the present work the method developed by Cole et al. (1967), in which growing bacteria were pipetted into $\mathrm{HClO}_{4}$, did not extract 
the ATP from $Z$. anaerobia satisfactorily, so they were centrifuged before extracting the ATP. This was done within $5 \mathrm{~min}$., the organisms being centrifuged for $2 \mathrm{~min}$. at $20,000 \mathrm{~g}$ at room temperature in a Servall Superspeed SS-I centrifuge. ATP was extracted from the unwashed packed organisms by using $0.6 \mathrm{~N}-\mathrm{H}_{2} \mathrm{SO}_{4}$ as described by Forrest \& Walker (1965) except that $20 \mathrm{~mm}-\mathrm{Na}_{3} \mathrm{PO}_{4}$ was used to neutralize the acid instead of $\mathrm{KOH}$.

The apparatus used was a high-gain photomultiplier tube (E.M.I. type 6097S) with a Nuclear Enterprises type N.E. 5353 high voltage supply (Damoglou \& Dawes, I968). The current output of the tube was measured after conversion to voltage on a Yellow Springs Model 80 laboratory recorder (Yellow Springs Instrument Co. Inc., Yellow Springs, Ohio, U.S.A.). The firefly lantern extract and the estimation method were as described by Forrest \& Walker (I965).

Viability determination by anaerobic slide culture. The slide culture method of Postgate, Crumpton \& Hunter (I961) was modified slightly for anaerobic bacteria. Since Zymomonas anaerobia, long thought to grow only anaerobically (Shimwell, 1937, 1950) was found during this work to tolerate oxygen and to grow slowly under aerobic conditions, rigid precautions to ensure anaerobiosis during harvesting and preparation of the slide culture were not necessary. Starved suspensions were diluted I/Io with sterile $67 \mathrm{~mm}$-phosphate buffer ( $\mathrm{pH} \mathrm{6.8)}$ and one drop applied to the agar on the slide. After drying and removal of excess moisture, the cultures were sealed with sterile buffer under circular coverslips, placed in Petri dishes and incubated in an anaerobic jar filled with oxygen-free $N_{2}$ at $22^{\circ}$, high viability samples for $48 \mathrm{hr}$, samples of low viability for $72 \mathrm{hr}$, and the numbers of divided and undivided bacteria (single or paired) were counted under a Watson Microsystem 70 phase-contrast microscope and the \% viability calculated. No further increase in the $\%$ viability was noted when the incubation times were prolonged further.

Extraction of amino acid pool. Bacteria $(5 \mathrm{mg}$. dry wt) were centrifuged down and suspended in $5 \mathrm{ml}$. water. After adding one drop of $2 \mathrm{~N}_{-} \mathrm{H}_{2} \mathrm{SO}_{4}$, the suspension was heated in a water bath at $100^{\circ}$ for 10 min. with a glass bulb condenser on the tube. The cell debris was centrifuged down, and the supernatant fluid analysed for amino acids.

Chemical determinations. Ethanol was determined enzymically (Kaplan \& Ciotti, I957) by using liver alcohol dehydrogenase 340-L2 (Sigma-London Chemical Co.). Standards prepared from ethanol standardized by specific gravity determination were estimated simultaneously. Glucose in suspensions of starved bacteria was determined by the method of Nelson (1944), but for bacterial growth media the glucose oxidase + horseradish peroxidase method (Huggett \& Nixon, 1957) with the Boehringer blood sugar test combination TC-M-II was used, since constituents of the peptone produced false positive reactions with the Nelson reagent. Pyruvate was estimated by the direct method of Friedemann \& Haugen (1943), amino acids by the method of Yemm \& Cocking (1955) and carbohydrate by the anthrone method of Trevelyan \& Harrison (1952) as modified by Binnie, Dawes \& Holms (1960). Ammonia was determined by the indophenol method of Chaney \& Marbach (I962), polyphosphate as described by Harold (1960) and poly- $\beta$-hydroxybutyrate by the method of Law \& Slepecky (I96I), using the isolation procedure of Williamson \& Wilkinson (1958). Cell protein was determined by the method of Lowry, Rosebrough, Farr \& Randall (195I) after suspensions had been boiled for 6 min. in $2.5 \mathrm{~N}-\mathrm{NaOH}$. 
Bovine serum albumin was used as standard. Cold-acid-soluble nucleotides were estimated by extraction of $5 \mathrm{mg}$. dry wt bacteria in ice-cold $0.7 \mathrm{~N}-\mathrm{HClO}_{4}$ for $10 \mathrm{~min}$. at $0^{\circ}$. After centrifugation at $25,000 \mathrm{~g}$, the residue was washed three times with $0.7 \mathrm{~N}-\mathrm{HClO}_{4}$, the supernatant fluids and washings combined and the extinction read at $260 \mathrm{~nm}$. The residue was hydrolysed with $0.3 \mathrm{~N}-\mathrm{KOH}$ for $90 \mathrm{~min}$. at $37^{\circ}$. The RNA content was determined on the basis of the extinction at $260 \mathrm{~nm}$., as described by Fleck \& Munro (1962), with yeast RNA hydrolysed by the same procedure as a standard. DNA was estimated on the cold- $\mathrm{HClO}_{4}$-washed residue by the indole method of Ceriotti (1952).

Materials and chemicals. Analytical reagent grade chemicals were used where available. Firefly lanterns and ATP were obtained from Sigma-London Chemical Co., (London, S.W.6) and NAD from the Boehringer Corporation (London) Ltd. (London, W.5).

Buffer. $\mathrm{KH}_{2} \mathrm{PO}_{4}(0.067 \mathrm{M})$ was adjusted to $\mathrm{pH} 6.8$ with $5 \mathrm{~N}-\mathrm{NaOH}$.

\section{RESULTS}

Changes in cellular constituents during growth and starvation

Carbohydrate content. Zymomonas anaerobia contained about $4 \%$ of its dry wt as carbohydrate, which did not change on starvation up to $\mathrm{II} 8 \mathrm{hr}$ in $\mathrm{N}_{2}$. Z. mobilis contained about $5 \%(\mathrm{w} / \mathrm{w})$ carbohydrate, which decreased to about $3 \%$ on starvation up to II $8 \mathrm{hr}$ under $\mathrm{N}_{2}$.

Poly- $\beta$-hydroxybutyrate and polyphosphate. These polymers were absent from both organisms.

DNA content. Zymomonas anaerobia contained about $2 \cdot 7 \%(\mathrm{w} / \mathrm{w})$ DNA, and this remained stable on starvation to at least $138 \mathrm{hr}$.

Protein content. The protein content of Zymomonas anaerobia was examined at various stages of growth and during starvation of the harvested and washed bacteria under $\mathrm{N}_{2}$. During growth the protein content remained essentially constant at 65 to $69 \%$ of the dry wt but decreased to $54 \%$ late in the stationary phase. During starvation of washed suspensions the protein content did not change significantly during starvation up to $\mathrm{I} 50 \mathrm{hr}$; this result was not altered when the cells were either shaken or left stationary. The protein content was not affected when the glucose concentration in the growth medium was varied from I to $5 \%(\mathrm{w} / \mathrm{v})$.

The effect of starvation on the qualitative pattern of individual proteins in the soluble fraction of cell extracts was examined by disc electrophoresis on polyacrylamide gel. In extracts of unstarved organisms about I 4 different protein bands were distinguished, of which five were especially prominent. After I59 hr starvation, I3 bands were still evident and the same five bands were still prominent. There did not seem to be any major or significant changes in individual protein bands in samples taken during this period.

Amino acids and ammonia. The concentration of ammonia and amino acids in the hot-water-extractable pool of Zymomonas anaerobia did not change in starvation periods up to $24 \mathrm{hr}$. Variable amounts of ammonia (from 0.1 to $0.5 \mu \mathrm{mole} / \mathrm{mg}$. dry wt) and amino acids $(0.02$ to $0.2 \mu \mathrm{mole} / \mathrm{mg}$. dry wt) were released into the medium during these periods; in some experiments as much as I $\mu$ mole ammonia/mg. dry weight was noted. 
RNA and cold-acid-soluble nucleotide pool. Zymomonas anaerobia has a high content of RNA ( 17 to $25 \%$, average $22 \%$, of the dry wt of freshly harvested late exponential phase organisms). On prolonged starvation, the RNA content decreased drastically to as low as $3 \%$ after $\mathrm{I} 38 \mathrm{hr}$ (Fig. I A). During this period considerable amounts of material having an absorption maximum at $260 \mathrm{~nm}$. were released into the medium, and when expressed as RNA this accounted for all the RNA degraded, since the cold-acid-soluble nucleotide pool remained essentially constant. The degradation of RNA began immediately and continued in a linear fashion during starvation. The degradation was suppressed when the organisms were starved in the presence of $33 \mathrm{mM}-\mathrm{MgCl}_{2}$ (Fig. I A).
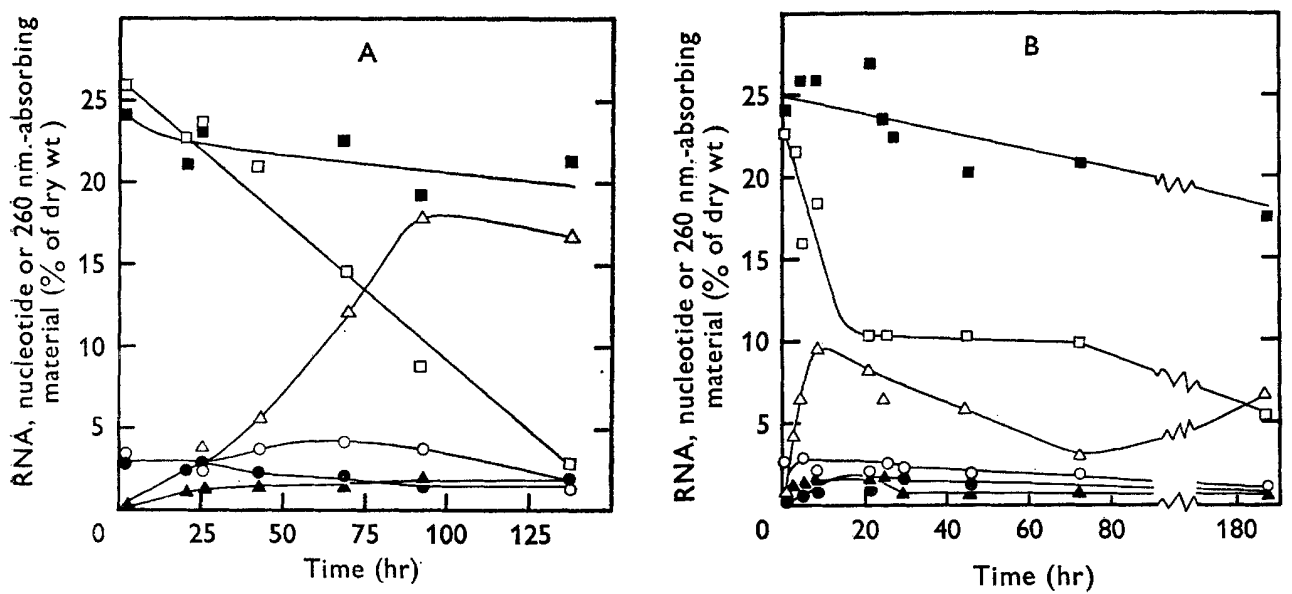

Fig. I. Effect of $\mathrm{Mg}^{2+}$ ions on the degradation of RNA by anaerobically starved $Z$. anaerobia (A) and $Z$. mobilis (B). Bacteria from late exponential phase (10 mg. dry wt) were harvested aseptically and suspended in $10 \mathrm{ml}$. sterile $67 \mathrm{~mm}$ phosphate buffer (pH 6.8) in $50 \mathrm{ml}$. conical flasks under $\mathrm{N}_{2}$, with and without $33 \mathrm{mM}-\mathrm{MgCl}_{2}$. Flasks were removed at intervals, bacteria centrifuged down and extinction of the supernatant fluid at $260 \mathrm{~nm}$. measured. Bacteria were fractionated into cold $0.7 \mathrm{~N}-\mathrm{HClO}_{4}$-soluble nucleotide pool and RNA, and these were estimated as described in Methods. Results are expressed as \% of dry wt bacteria, with yeast RNA as standard. RNA content: $\square$, in presence of $\mathrm{MgCl}_{2} ; \square$, in absence of $\mathrm{MgCl}_{2}$. Cold acid-soluble nucleotide pool: - , in presence of $\mathrm{MgCl}_{2} ; \mathrm{O}$, in absence of $\mathrm{MgCl}_{2}$. $260 \mathrm{~nm}$.-absorbing material: $\boldsymbol{\Delta}$, in presence of $\mathrm{MgCl}_{2} ; \Delta$, in absence of $\mathrm{MgCl}_{2}$.

The RNA content of Zymomonas mobilis in late exponential phase (average $22 \%$ of dry wt) was very similar to that of $Z$. anaerobia, but marked differences in the rate of RNA degradation were observed for $Z$. mobilis. After anaerobic starvation for $24 \mathrm{hr}$ the RNA content had decreased from $22 \%$ to II \%; this degradation was

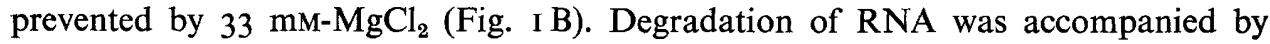
a release of $260 \mathrm{~nm}$--absorbing material into the medium, while the cold-acid-soluble nucleotide pool remained constant. This initial rapid rate of RNA breakdown then declined and for the next $150 \mathrm{hr}$ was about the same as the rate of breakdown in the presence of $\mathrm{MgCl}_{2}$. The initial rapid release of $260 \mathrm{~nm}$.-absorbing material in the first $24 \mathrm{hr}$ appeared to be followed by a slow re-utilization during the succeeding $50 \mathrm{hr}$, an effect never observed with $Z$. anaerobia. $\mathrm{MgCl}_{2}$ suppressed this release of nucleotides.

Intracellular level of ATP during growth. During growth, the intracellular ATP 
content increased as shown in Fig. 2, until the last generation of growth was reached, when a rapid and exponential decrease in ATP began and continued after the glucose in the medium had been exhausted. This decrease was consistently observed in several experiments. In some cases it could be correlated with a decrease in growth rate indicating the approach to the stationary phase, but in other experiments exponential growth was still occurring when the decrease in ATP began.

Effect of addition of substrates on endogenous ATP levels. Within $2 \mathrm{hr}$ of addition of a pulse of glucose (final concentration $2.5 \mathrm{mM}$ ) to a suspension of Zymomonas anaerobia which had been starved for $25 \mathrm{hr}$ under oxygen-free $\mathrm{N}_{2}$, the glucose had

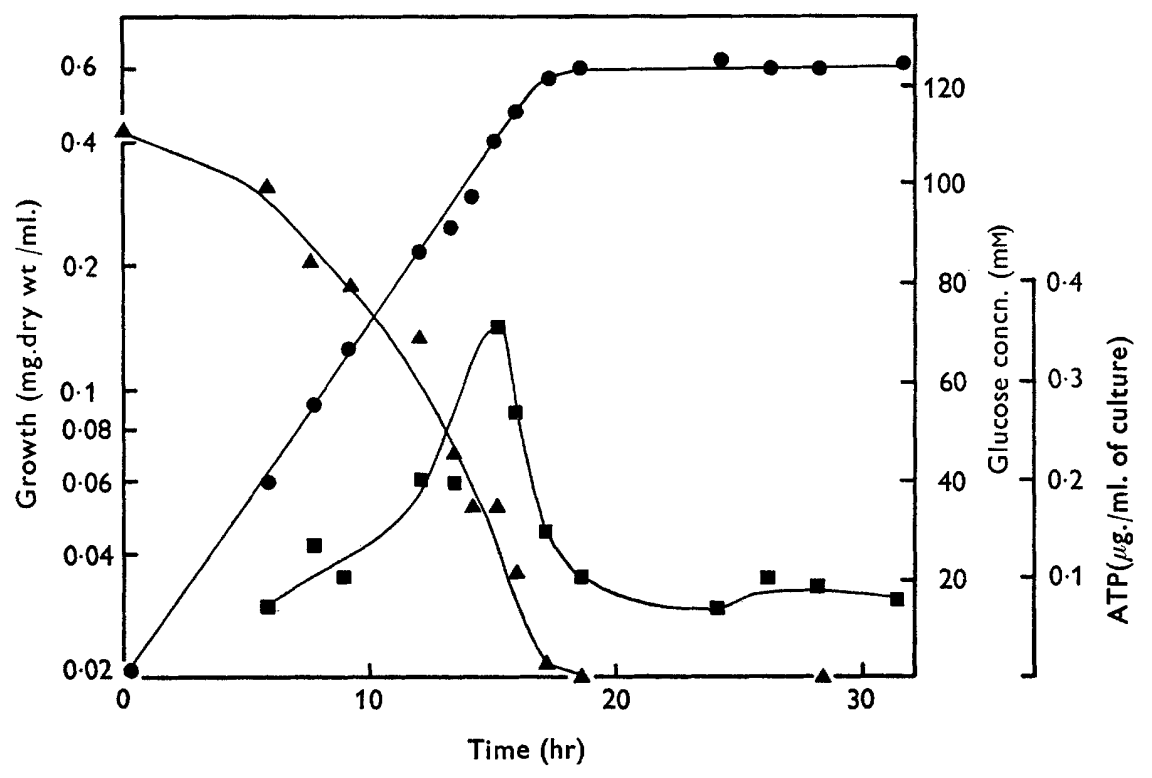

Fig. 2. Intracellular ATP during growth and short-term starvation in growth medium. Zymomonas anaerobia was grown anaerobically at $20^{\circ}$ and samples were removed aseptically at intervals for measurement of growth $(\boldsymbol{\theta})$ and glucose concentration $(\boldsymbol{\Delta})$ and extraction of ATP. $\boldsymbol{w}$, ATP content ( $\mu \mathrm{g} . / \mathrm{ml}$. culture).

entirely disappeared from the supernatant fluid (Fig. 3). The concentration of ATP within the cell reflected closely the pattern of glucose utilization. There was a bi-phasic formation of ethanol, the inflexion point (2.I $\mu$ moles) corresponding to I mole ethanol/mole glucose added. There then followed a second phase of ethanol formation reaching a maximum with $4 \cdot 5 / 2 \cdot 2=2$ moles ethanol formed $/ \mathrm{mole}$ glucose added. The subsequent loss of ethanol from the supernatant fluid was most probably due to volatilization. In a similar experiment in which glucose was replaced by pyruvate there was no detectable ATP formation, thus confirming that decarboxylation of pyruvate was not an energy-yielding reaction. To test whether the organism can obtain energy from ethanol, the effect of a pulse of ethanol on the ATP levels of a $24 \mathrm{hr}$-starved suspension of $Z$. anaerobia was determined under both aerobic and anaerobic conditions (Fig. 4). The results suggest that even under anaerobic conditions the organism formed small amounts of ATP from ethanol. 


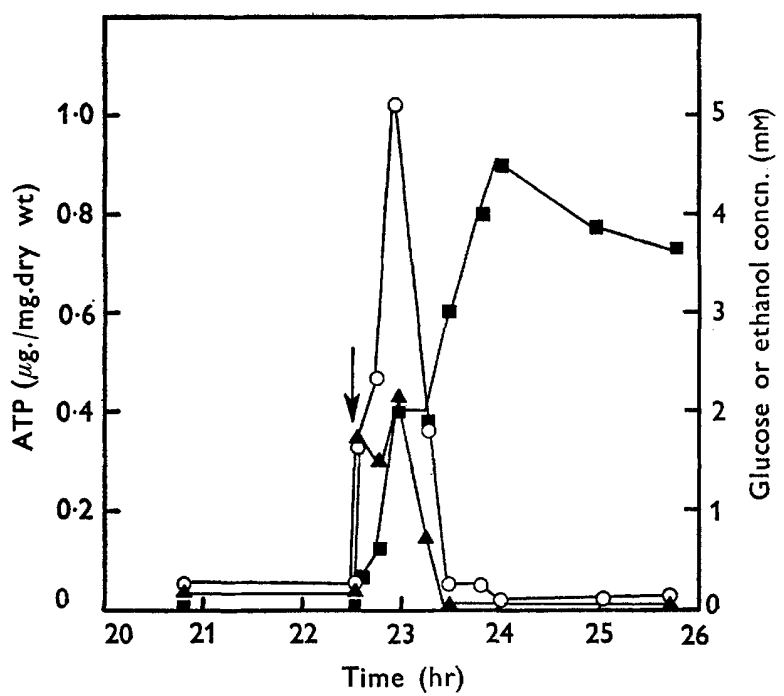

Fig. 3. Effect of anaerobic addition of glucose on ATP levels in starved Zymomonas anaerobia. Bacteria $(265 \mathrm{mg}$. dry wt) from late exponential phase were harvested aseptically and suspended in $250 \mathrm{ml}$. sterile $67 \mathrm{~mm}$-phosphate buffer (pH 6.8) and oxygen-free $\mathrm{N}_{2}$ bubbled through the suspension. After starvation for $22 \mathrm{hr} 625 \mu$ mole glucose were added anaerobically (at point shown by arrow) and samples removed at intervals for assay of ATP (O) $\mu \mathrm{g}$. ATP $/ \mathrm{mg}$. dry wt of organisms. The culture supernatant fluids were analysed for

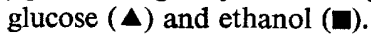

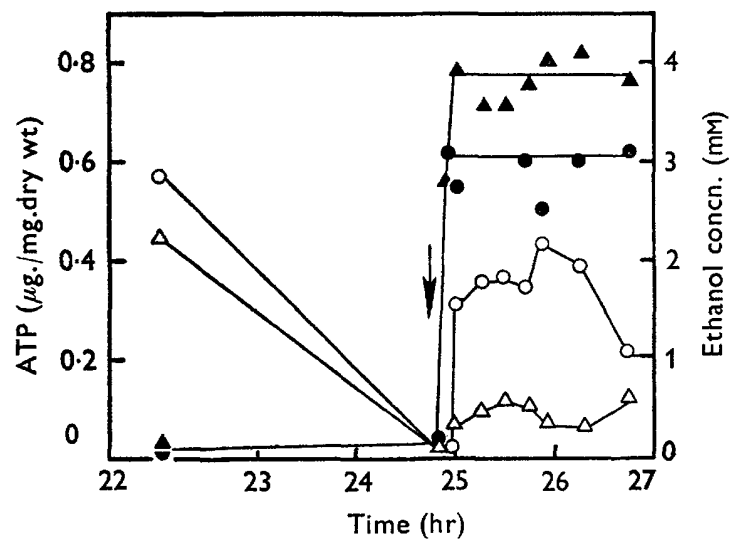

Fig. 4. Effect of addition of ethanol, both aerobically and anaerobically, on ATP levels in starved Zymomonas anaerobia. Conditions were as for Fig. 3, except that two flasks were set up, one bubbled with air, the other with oxygen-free $\mathrm{N}_{2}$. After 24 -hr starvation (at the point shown by an arrow) I m-mole ethanol was added to each flask (without introduction of air), and samples removed at intervals. Organisms were harvested by centrifugation and ATP extracted from them. The supernatant fluids were analysed for ethanol concentration: , aerobic; $\Delta$, anaerobic. ATP pool ( $\mu \mathrm{g}$. ATP/mg. dry wt); $\bigcirc$, aerobic; $\triangle$, anaerobic. 


\section{Effect of starvation on ability of Zymomonas anaerobia to produce ATP from glucose}

The ability to metabolize glucose, and to form ATP from it, remained unimpaired after $\mathrm{I} 43 \mathrm{hr}$ starvation (Fig. 5). In another experiment the starvation was extended to I5 days, after which time the ability to metabolize glucose was impaired, and only low amounts of ATP were formed (maximum, $0.6 \mu \mathrm{g}$. $/ \mathrm{mg}$. dry wt). Bacteria starved for I5 days took $30 \mathrm{hr}$ to metabolize I m-mole of glucose as compared with I to $2 \mathrm{hr}$ after starvation for $143 \mathrm{hr}$.

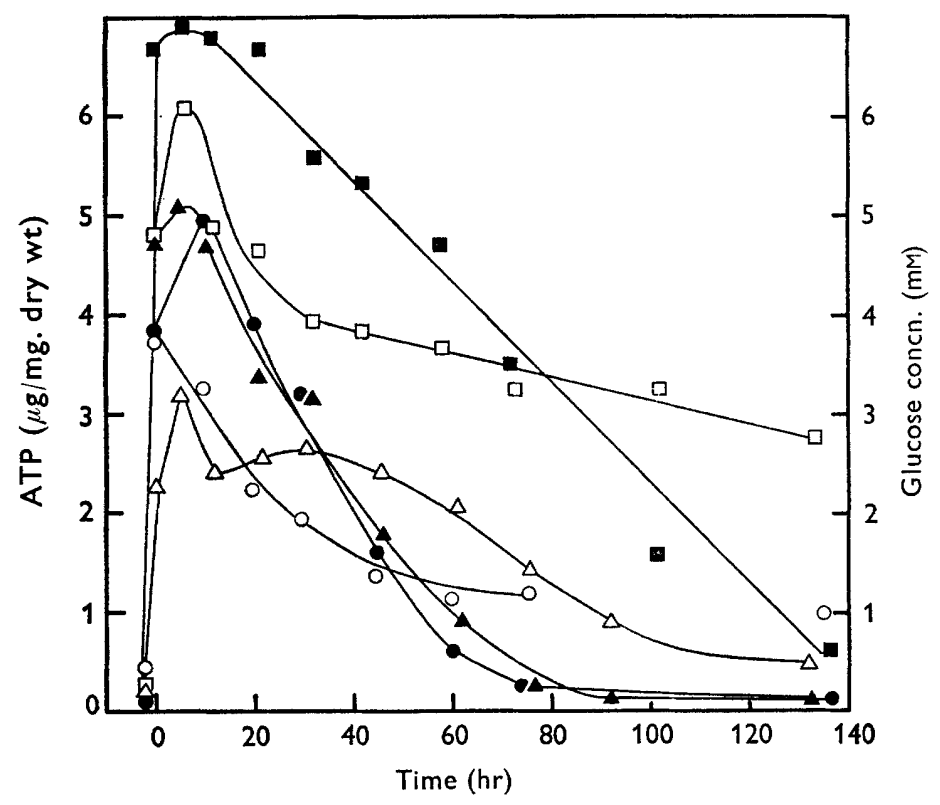

Fig. 5. Effect of extended starvation on the ability of Zymomonas anaerobia to produce ATP from glucose anaerobically. Conditions were as for Fig. 3, except that three flasks were set up, each containing $0.4 \mathrm{mg}$. dry wt organism $/ \mathrm{ml}$. and each starved for different periods. After starvation, I m-mole glucose was added anaerobically, and samples removed at intervals. Organisms were collected by centrifugation and ATP extracted. The supernatant fluids were analysed for glucose. Solid symbols represent glucose, open symbols ATP content ( $\mu \mathrm{g}$./mg. dry wt), for $23 \mathrm{hr}$ (circles); $47 \mathrm{hr}$ (triangles) and $\mathrm{I} 43 \mathrm{hr}$ (squares) starvation.

\section{Relationship between viability of Zymomonas anaerobia and intracellular concentrations of RNA and ATP}

Viability decreased exponentially as soon as starvation began, as might be expected since Zymomonas anaerobia contains no energy reserves to protect against starvation. The decrease in viability was accompanied by an exponential decrease in intracellular ATP which was most marked during the initial $6 \mathrm{hr}$. During longer periods of starvation $\mathrm{Mg}^{2+}$, which prevented degradation of RNA (Fig. I), seemed to protect the populations. After $175 \mathrm{hr}$ starvation in the presence of $33 \mathrm{mM}-\mathrm{MgCl}_{2}$, the population was $22 \%$ viable as compared with only $3 \%$ in the absence of $\mathrm{MgCl}_{2}$ (Fig. 6). $\mathrm{Mg}^{2+}$ did not have a significant effect on the ATP content of the organisms. 
An experiment was made to study the effect on ATP amounts of adding glucose to a culture of low viability. Viability was followed as a function of time; after I $80 \mathrm{hr}$, when the viability had decreased to less than $3 \%$, glucose was added anaerobically (final concentration, $5 \mathrm{~mm}$ ). The rates of disappearance of glucose and formation and disappearance of ATP were very similar to those shown in Fig. 5. It is apparent that the ability to produce ATP in response to glucose is not lost on prolonged starvation and is, therefore, not related to viability as measured by slide culture.

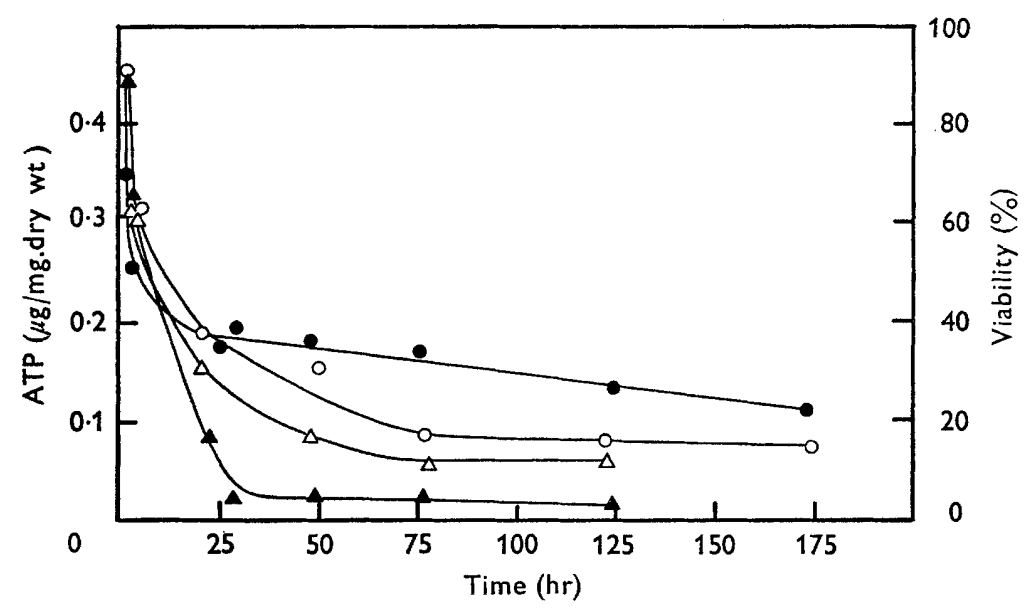

Fig. 6. Effect of prolonged starvation on intracellular ATP levels and viability of Zymomonas anaerobia with and without $\mathrm{Mg}^{2+}$. Conditions were as for Fig. 3. $\triangle$, Intracellular ATP concentration and $\boldsymbol{\Delta}$, viability in the absence of $\mathrm{MgCl}_{2} ; \mathrm{O}$, ATP concentration and $\boldsymbol{\bullet}$, viability in the presence of $33 \mathrm{mM}-\mathrm{MgCl}_{2}$.

\section{DISCUSSION}

A study of the intracellular constituents of Zymomonas anaerobia and Z. mobilis which are degraded on starvation suggests that, in both organisms, the only constituent which is significantly broken down is RNA. Breakdown of RNA seems to be a common (though by no means universal) response of bacteria to starvation. Thus Aerobacter aerogenes (Strange, Dark \& Ness, 1961), Pseudomonas aeruginosa (Gronlund \& Campbell, 1965), Escherichia coli (Dawes \& Ribbons, 1965), Sarcina lutea (Burleigh \& Dawes, 1967) and Streptococcus lactis (Thomas, 1968) all degrade RNA during starvation. Anaerobic organisms would thus not seem to differ from aerobes in this respect. In all cases, the breakdown of RNA is prevented by $\mathrm{Mg}^{2+}$, which is well known as a ribosome-stabilizing agent (Bowen, Dagley \& Sykes, I959; Wade, I96I). In the case of $P$. aeruginosa, Gronlund \& Campbell (I965) have shown that the ribosomes are degraded. Fig. 6 shows that $\mathrm{Mg}^{2+}$ ions exert a considerable protective effect against loss of viability in $Z$. anaerobia. In this respect, the organism resembles A. aerogenes (Strange \& Shon, 1964; Strange \& Hunter, 1967) and S. lactis (Thomas \& Batt, I968) rather than E. coli (Dawes \& Ribbons, 1965) or S. lutea (Burleigh \& Dawes, 1967), where survival is not prolonged by $\mathrm{Mg}^{2+}$ ions. Ethanol, unlike pyruvate, leads to the formation of small amounts of ATP, even under anaerobic conditions. This observation suggests that the metabolism of $Z$. anaerobia may be somewhat 
more complex than has hitherto been envisaged. The higher level of ATP formed in aerated suspensions is in keeping with the ability of washed cell suspensions of anaerobically grown $Z$. anaerobia to oxidize ethanol without a lag (P. J. Large, unpublished observation). This may indicate that ethanol can be metabolized further by $Z$. anaerobia and that this metabolism may be energy-yielding. Belaïch \& Senez (1965) found that $Z$. mobilis would oxidize ethanol, but suggested that the process was not energy-yielding.

While the ability to produce ATP is ultimately impaired by starvation, the actual intracellular amounts of ATP seem to be correlated with viability of the cells (Fig. 6). Although several workers (e.g. Cole et al. 1967 with Escherichia coli) have studied the effects of starvation on ATP levels, the only work of this kind that we are aware of in which viabilities were measured is that of Strange, Wade \& Dark (I963). In contrast to the present observations, these workers were unable to detect any correlation between intracellular ATP content of Aerobacter aerogenes and viability, the ATP amounts reflecting largely the oxygen tension and solute concentration. A higher ATP content in E. coli starved aerobically was also observed by Cole et al. (1967). We have been unable to discover any correlation between viability and ability to produce ATP from glucose in Zymomonas anaerobia.

The marked decrease in intracellular ATP in the last generation before growth on glucose ceased was observed in several experiments. This phenomenon does not seem to have been explicitly reported by other workers. Forrest \& Walker (1965), in Streptococcus faecalis growing on glucose, only observed a decline in ATP amounts when the stationary phase had been reached. Cole et al. (1967) measured the ATP pool in Escherichia coli under various conditions. When the organisms were grown anaerobically an apparent decline in ATP content did occur; in defined medium containing glucose the amount of ATP decreased abruptly in the stationary phase, while in glucose + yeast-extract medium a slow decrease in ATP content occurred in the last half-generation before growth ceased. We suggest that the decrease in ATP content in Zymomonas anaerobia during growth on glucose (which is here behaving as energy source) is an indication that the organisms are becoming energy limited. In cultural conditions where growth is limited by some other constituent of the medium the ATP pool might be expected to behave differently.

We thank Miss L. Jackson and Mr D. J. Murden for expert technical assistance. This work was sponsored in part by the European Research Office of the United States Army.

\section{REFERENCES}

BELAÏCH, J.-P. \& SeNEZ, J. C. (1965). Influence of aeration and of pantothenate on growth yields of Zymomonas mobilis. Journal of Bacteriology 89, 1195.

Binnie, B., Dawes, E. A. \& Holms, W. H. (1960). Metabolism of Sarcina lutea. IV. Patterns of oxidative assimilation. Biochimica et Biophysica Acta 40, 237.

Bowen, T. J., DAGLeY, S. \& SykeS, J. (1959). A ribonucleoprotein component of Escherichia coli. Biochemical Journal 72, 419.

Burleigh, I. G. \& Dawes, E. A. (1967). Studies on the endogenous metabolism and senescence of starved Sarcina lutea. Biochemical Journal ro2, 236.

Ceriotti, G. (I952). A microchemical determination of desoxyribonucleic acid. Journal of Biological Chemistry 198, 297.

Chaney, A. L. \& MaRbaCh, E. P. (1962). Modified reagents for determination of urea and ammonia. Clinical Chemistry 8, 130. 
Cole, H. A., Wimpenny, J. W. T. \& Hughes, D. E. (1967). The ATP pool in Escherichia coli. I. Measurement of the pool using a modified luciferase assay. Biochimica et Biophysica Acta I43, 445 .

Damoglou, A. P. \& Dawes, E. A. (1968). Studies on the lipid content and phosphate requirement of glucose- and acetate-grown Escherichia coli. Biochemical Journal I10, 775.

DAvIs, B. J. (1964). Disk electrophoresis. II. Method and application to human serum proteins. Annals of the New York Academy of Sciences 121, 404.

Dawes, E. A. \& Holms, W. H. (1958). Apparatus for aeration and sampling of bacteria during growth and metabolic studies. Nature, London $178,318$.

Dawes, E. A. \& RibBons, D. W. (I962). The endogenous metabolism of micro-organisms. Annual Review of Microbiology 16, 241 .

Dawes, E. A. \& RibBons, D. W. (1964). Some aspects of the endogenous metabolism of bacteria. Bacteriological Reviews 28, 126.

Dawes, E. A. \& Ribbons, D. W. (1965). Studies on the endogenous metabolism of Escherichia coli. Biochemical Journal 95, 332.

Dawes, E. A., Ribbons, D. W. \& Large, P. J. (1966). The route of ethanol formation in Zymomonas mobilis. Biochemical Journal 98, 795.

ElsDen, S. R. \& PeEL, J. L. (1958). Metabolism of carbohydrates and related compounds. Annual Review of Microbiology 12, I45.

ENTNER, N. \& Doudoroff, M. (I952). Glucose and gluconic acid oxidation of Pseudomonas saccharophila. Journal of Biological Chemistry 196, 853.

FleCK, A. \& MunRo, H. N. (1962). The precision of ultraviolet absorption measurements in the Schmidt-Thannhauser procedure for nucleic acid estimation. Biochimica et Biophysica Acta 55, 57 I.

ForREST, W. W. \& WALKER, D. J. (1965). Synthesis of reserve materials for endogenous metabolism in Streptococcus faecalis. Journal of Bacteriology 89, 1448.

Friedemann, T. E. \& Haugen, G. E. (I943). Pyruvic acid. II. The determination of keto acids in blood and urine. Journal of Biological Chemistry 147, 415.

Gronlund, A. F. \& Campbell, J. J. R. (I965). Enzymatic degradation of ribosomes during endogenous respiration of Pseudomonas aeruginosa. Journal of Bacteriology 9o, I.

HaROLD, F. M. (1960). Accumulation of inorganic polyphosphate in mutants of Neurospora crassa. Biochimica et Biophysica Acta $45,172$.

HugGetT, A. ST. G. \& Nixon, D. A. (I957). Use of glucose oxidase, peroxidase and $o$-dianisidine in determination of blood and urinary glucose. Lancet ii, 368 .

Kaplan, N. O. \& CrotrI, M. M. (1957). Enzymatic determination of ethanol. Methods in Enzymology 3, 253.

LARGE, P. J. \& Dawes, E. A. (1966). Endogenous metabolism of Zymomonas anaerobia and Peptococcus prevotii. Ninth International Congress for Microbiology, Moscow, 1966. Abstracts of papers, p. 120.

LAW, J. H. \& SLEPECKY, R. A. (I96r). Assay of poly- $\beta$-hydroxybutyric acid. Journal of Bacteriology 82, 33 .

Lowry, O. H., Rosebrough, N. J., Farr, A. L. \& Randall, R. J. (195I). Protein measurement with the Folin phenol reagent. Journal of Biological Chemistry 193, 265.

McGill, D. J. (1966). The carbohydrate metabolism of Zymomonas anaerobia. Ph.D. Thesis, University of Hull.

McGill, D. J., Dawes, E. A. \& RibBons, D. W. (1965). Carbohydrate metabolism and growth-yield coefficients of Zymomonas anaerobia. Biochemical Journal 97, $44 P$.

Nelson, N. (1944). A photometric adaptation of the Somogyi method for the determination of glucose. Journal of Biological Chemistry 153, 375.

Postgate, J. R., Crumpton, J. E. \& Hunter, J. R. (I96I). The measurement of bacterial viabilities by slide culture. Journal of General Microbiology 24, 15.

SHIMweLl, J. L. (1937). Study of a new type of beer disease bacterium (Achromobacterium anaerobium spec. nov.) producing alcoholic fermentation of glucose. Journal of the Institute of Brewing 43, 507 .

SHIMwELL, J. L. (I950). Saccharomonas, a proposed new genus for bacteria producing a quantitative alcoholic fermentation of glucose. Journal of the Institute of Brewing 56, I79.

Stern, I. G., WANG, C. H. \& Gilmour, C. M. (I960). Comparative catabolism of carbohydrates in Pseudomonas species. Journal of Bacteriology 79, 601. 
Strange, R. E., Dark, F. A. \& Ness, A. G. (I96I). The survival of stationary phase Aerobacter aerogenes stored in aqueous suspension. Journal of General Microbiology 25, 6I.

StRANGE, R. E. \& HUNTER, J. R. (1967). Effect of magnesium on the survival of bacteria in aqueous suspension. In Microbial Physiology and Continuous Culture. Ed. by E. O. Powell, C. G. T. Evans, R. E. Strange and D. W. Tempest, p. 102. London: Her Majesty's Stationery Office.

STRANGE, R. E. \& SHON, M. (1964). Effect of thermal stress on viability and ribonucleic acid of Aerobacter aerogenes in aqueous suspension. Journal of General Microbiology 34, 99.

Strange, R. E., Wade, H. E. \& Dark, F. A. (1963). Effect of starvation on adenosine triphosphate concentration in Aerobacter aerogenes. Nature, London 199, 55.

Thомаs, T. D. (1968). Metabolism of lactic acid bacteria. Ph.D. Thesis, Massey University, New Zealand.

Thомas, T. D. \& BatT, R. D. (1968). Survival of Streptococcus lactis in starvation conditions. Journal of General Microbiology 50, 367.

Trevelyan, W. D. \& Harrison, J. S. (1952). Studies on yeast metabolism. I. Fractionation and microdetermination of all carbohydrates. Biochemical Journal 5o, 298.

WADE, H. E. (196r). The autodegradation of ribonucleoprotein in Escherichia coli. Biochemical Journal 78, 457.

Williamson, D. H. \& Wilkinson, J. F. (1958). The isolation and estimation of poly- $\beta$-hydroxybutyrate inclusions of Bacillus species. Journal of General Microbiology 19, 198.

Yemm, E. W. \& Cocking, E. C. (I955). The determination of amino acids with ninhydrin. Analyst, London 80, 209. 